\title{
STRUGGLE AGAINST CHOLERA EPIDEMICS IN IMPERIAL TIME KHARKIV AS A SIGNIFICANT FACTOR OF PUBLIC HEALTH: HISTORICAL EXPERIENCE
}

DOI: $10.36740 /$ WLek202105136

\author{
Ihor Yu. Robak, Volodymyr A. Alkov, Hanna L. Demochko, Oleksandr V. Chernukha \\ KHARKIV NATIONAL MEDICAL UNIVERSITY, KHARKIV, UKRAINE
}

\begin{abstract}
The aim: The aim of the research is to determine and systematize administrative and medical measures aimed at curbing cholera in the city of Kharkiv in the time of the Russian Empire, to assess the relevance of the experience in fighting the disease, to determine the impact of epidemics and anti-epidemic measures on Kharkiv residents' public health. Materials and methods: General scientific and specific historical methods were used, and methods of related sciences were applied as well. The main methods of historical research included, in particular, historical analytical, chronological and comparative historical; methods of medical statistics, etc. The historiography of the issue was analyzed, unpublished archival materials, local press were studied.

Conclusions: Despite the progress made, mortality remained high in general, proving the public health system had to be reorganized. The death rate shocked the local community so much that the authorities had to apply an information blockade. Anti-epidemic components included explanatory work by priests and police, sanitary measures, measures on strict compliance with observation and quarantine, food supplies to the blocked city and free medicine dispensation, involvement of all available medical institutions, and the establishment of special temporary facilities, actual mobilization of medical personnel. It was impossible to act in the other way, because the treatment methods seemed to be ineffective, like today, under the COVID-19 pandemic. When the medical component is proved ineffective in fighting the epidemic, relatively effective administrative measures, tried and tested over the centuries reasonably seem to be useful, and this experience has not lost its relevance.
\end{abstract}

KEY WORDS: epidemic, public health, history, health care, the Russian Empire

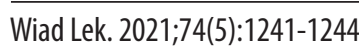

\section{INTRODUCTION}

The fight against epidemics is still relevant. The epidemic outbreaks of the 21 st century in general and the coronavirus pandemic in particular have once again demonstrated that society is unsafe when faced the global challenge we see today.

The world has often suffered from various infectious diseases and has successfully overcome most of them; rich historical experience in struggle has been accumulated and can be used today. Given the local history, some parallels are evident and the experience in fighting epidemics in a particular city in a certain chronological period can be allocated. The authors have chosen the city of Kharkiv as a study object, and struggle against cholera, raging in the city in the empire time, as a subject.

\section{THE AIM}

The aim of the research is to determine and systematize administrative and medical measures aimed at curbing cholera in the city of Kharkiv in the empire time, to assess the relevance of the experience in fighting the disease, to determine the impact of epidemics and anti-epidemic measures on Kharkiv residents' public health.

\section{MATERIALS AND METHODS}

According to the aim of the research, the methods can be divided into general scientific, historical and related sciences. The main methods were ones of historical research. The most useful were analytical, chronological and comparative historical methods. Analysis of historical facts was the initial stage of the research. The materials were disclosed in problem and chronological order. The comparative historical method was applied to different stages of the anti-epidemic case development in Kharkiv.

During the research, the authors turned to the methods of historical demography. Thus, the methods of demographic statistics were useful for the analysis of empirical materials developed in the study of resistance to epidemics. A related scientific discipline such as "Social Medicine and Health Care Organization" provided methods of medical statistics, studying the factors affecting the population's health, studying morbidity and mortality, and an approach to the analysis of control methods for the most significant diseases, and also the conceptual apparatus.

In general, these pages of history are insufficiently studied in historiography. In pre-Soviet times, they were studied by D. Bagaliy and D. Miller in the famous monograph on the history of Kharkiv [1]. They highlighted the main 
ways taken by Kharkiv healthcare in the early stages of its development, including the fight against cholera. Soviet historians had no interest in studying the experience in health care organization at the local level in the pre-revolution period, as that experience was irrelevant to the Soviet health care system. Modern domestic researchers also did not study the issue. The only experience of its development is I. Robak's monograph "Organization of Health Care in Kharkiv during the Emperial Era (Early $18^{\text {th }}$ Century 1916)" [2], as well as the works by V. Alkov [3-4].

\section{REVIEW AND DISCUSSION}

Kharkiv citizens survived the first epidemic of cholera in 1830. It came from Astrakhan Region through the city of Izium. The sick appeared in the city on July 23 [5-6], as well as rumors of deliberate poisoning of wells and burial of people alive. The local doctor was almost killed by the crowd [1]. In the September, Governor M. Kakhovsky formed and headed the Sloboda-Ukrainian Governorate Committee to take measures against cholera. Relevant committees were also established in the districts [7-9]. In those horrible months, Cholera hospitals appeared in Kharkiv, maintained by merchants and pharmacists [1]. Anyone with medical education was mobilized to fight the epidemic. In December, the epidemic stopped [7]. According to the "List of cholera deaths in the city of Kharkiv", there were 497 those succumbed in 1830 [10-11]. Death from a terrible disease most affected the poor. In 1830, the cholera death rate in Kharkiv was almost 25 ppm.

In early June 1831, cholera returned. As the epidemic was much weaker, only one temporary City Cholera Hospital was established that time. The epidemic had receded by October. According to M. Tomashevsky, it took lives of 55 Orthodox Kharkivers, according to I. Chyzhevsky - 75 $[8-10,12]$.

The next cholera pandemic shook Kharkiv in late July 1847. Afterwards, cholera began to spread rapidly in the city. To fight the epidemic, the "Special Temporary Committee" was established on August 6 under the chairmanship of Governor S. Mukhanov, as well as authorities to "mitigate the spread of the disease." As there were not enough specialists in the city, a team of paramedics came to help from Moscow [13].

In addition, there were two special Cholera Hospitals in Kharkiv - V. Frankovsky's and F. Albrecht's. Military hospitals began admission of civilians sick with cholera $[1,13]$. The 1847 epidemic peak was in September. At the end of the month, it slowed down, and on October 16 came to an end. According to Kharkiv University professor A. Pitra, a total of 842 people died, that is, the cholera mortality rate at that time was about $20 \mathrm{ppm}$ [13].

A new outbreak occurred in 1848 [10, 14-15]. Ordinary anti-epidemic measures were organized $[14,16]$. According to official data, the number of victims was 792 people, and according to estimates by A. Pitra, $1734[10,17]$.

In July-September 1853, the foci of disease were in places with insanitary conditions prevailed. Both the medical board and the police monitored the compliance with orders All public and food institutions were inspected by a police doctor, such as workers' homes, hotels, taverns, etc. [18]. There was one temporary Cholera Hospital, and a cholera department was organized in the Kharkiv Governorate Municipal Hospital [19]. Medicines for cholera patients were disposed free of charge by pharmacies reimbursed for their expenses from public funds [20]. That year, 234 persons died of cholera in Kharkiv, according to A. Pitra. However, M. Tomashevsky and I. Chyzhevsky only among the Orthodox Christians counted 286 and 297 dead respectively [10].

The epidemic of 1855 was longer (from May to November). The Cholera Control Committee and the temporary Cholera Hospital operated again. The peak was in the end of June. According to M. Tomashevsky, the number of victims in Kharkiv during the whole period of the epidemic reached 878 Orthodox Christians, and I. Chyzhevsky specified the number 871 (their data practically coincide) [10, 21-22].

The first cholera epidemic of the reform era hit Kharkiv at the end of 1865 . The city was organizationally prepared. Therefore, cholera lasted only 6-8 weeks (according to various sources) and was actually localized in Zanetech district, the poorest part of the city [1,23-24]. The summer cholera epidemic began in June 1866 and was much more severe than the winter one due to weather conditions. In July-August, the disease was particularly severe in the lowlands along the river Lopan, spreading to other parts of the city. A total of 475 people died of cholera in Kharkiv in $1865-1866[1,10,23,25]$.

In July 1871, Kharkivers suffered from a new epidemic of cholera, lasted a while and mortality was relatively low, although the total number of deaths (due to high morbidity) reached significant numbers (according to some data -849 , according to other -906 people) $[10,26-28]$.

It should be noted that at the end of the $19^{\text {th }}$ century, superstitions remained mostly in rural areas, which was a significant achievement of the medicalization of public health. In 1892, superstitions were not very much observed anymore in Kharkiv, and, because of the measures taken, the epidemic did not develop. Even in the 1890s, cholera riots took place in some rural areas, but not in the city [4].

In Kharkiv, situated at the crossroad of quadruple-track railways, cholera appeared again in early October 1907, but the municipal sanitary and anti-epidemic services managed to prevent cholera from developing into an epidemic [29]. Patients with suspected cholera were removed from trains [30]. The governor insisted on explanations to population about risks from dirt and sewage. If the explanations failed to work, the guilty should have been brought to justice. Medical knowledge popularization was required, because population's cultural level was quite low, epidemics seriously affected population's perception and that interfered with anti-epidemic measures [31]. For example, lectures for population with full explanation were arranged at courses for workers in Petinskaya Street. Admission to the lectures was free [32]. Besides, instructions were distributed among the population [33]. 
However, there were serious problems. Due to the overcrowding of the Kharkiv Governorate Zemstvo Hospital with patients with other diseases, it was dangerous to admit cholera patients there, and the administration denied their admittance [34]. This was ignored, as cholera treatment at home was considered undesirable, and allowed only if a patient completely refused to be hospitalized [31]. In the face of the cholera threat, many categorically rejected to perform activist health care providers' duties because of their police functions. Those who wanted to get the position, the doctor of the 4th district of Kharkiv considered not only useless but also harmful [35] because they pursued their own goals, not philanthropic. Sometimes a janitor could pour a stinking liquid into the street right next to an anti-choleric poster arguing with a high school activist asking tricky questions about this []36. Homeowner Filonov, who lived near Alexander Hospital, complained that it drained smelly liquids during the cholera threat [37].

The next danger threatened Kharkiv in 1909, when the epidemic situation was extremely unfavorable. A city sanitary-executive commission was established to manage anti-choleric measures, including organization of professional cleaning and disinfection. That year Kharkiv avoided cholera [38-39]. The similar commission worked the following year, in 1910, but not so successfully - cholera affected 281 people (according to the other source - 315), there were 88 deaths. In the time of the epidemic, cholera barracks were opened in Nicholas Hospital and the city railway station [38, 40-44]. Due to the tried and tested anti-choleric measures, the last cholera outbreak of the empire time (1915) did not develop into an epidemic [45]. Note that the abdication of the tzar did not and could not end all troubles. Cholera did not leave the city even after the First World War and revolutionary events. The war and the economic crisis caused huge losses from cholera, pushing health care in the governorate to the level of the $18^{\text {th }}$ century [3].

\section{CONCLUSIONS}

So, for sure, the organization of struggle against cholera achieved great success. However, mortality remained high in general, especially among the poorest, proving the public health system had to be reorganized. The death rate shocked the local community so much that the authorities had to apply an information blockade, and were accused for that by activists, just like today COVID dissidents in different countries accuse the authorities. Anti-epidemic components included explanatory work through priests and police, sanitary measures (as well as engaging the police), measures on strict compliance with observation and quarantine, food supplies to the blocked city and free medicine dispensation, involvement of all available medical institutions, including the military, and the establishment of special temporary facilities, actual mobilization of medical personnel. It was impossible to act otherwise, because the treatment methods seemed to be ineffective, like today, under the COVID-19 pandemic. When the medical component is proved ineffective in fighting the epidemic, relatively effective administrative measures, tried and tested over the centuries reasonably seem to be useful. So, this experience has not lost its relevance. The study has proved that overcoming the epidemic cannot be a one-sided game - expected results can be achieved only with cooperation of the authorities, doctors and the city community.

\section{REFERENCES}

1. Bagalej D. I. Istoriya goroda Har'kova za 250 let ego sushchestvovaniya (s 1655 po 1905-j god). V 2-h t. [History of the City of Kharkiv During 250 Years of Its Existence (from 1655 to 1905). In 2 Vols.]. Kharkiv: Har'kovskaya knizhnaya fabrika im. M. V. Frunze. 1993. (in Russian).

2. Robakl. Yu. Organizacija ohorony zdorov'ja v Harkoviza impers'koi'doby (pochatok XVIII st. - 1916 r.) [Organization of Health Care in Kharkiv during the Emperial Era (Early 18th Century - 1916)]. Kharkiv: KhSMU; 2007. (in Ukrainian).

3. Alkov V. Epidemii revoliutsiinoi doby: kholera y tyf na Kharkivshchyni 1919 roku [Epidemics of the Revolutionary Era: Cholera and Typhus in the Kharkiv Region in 1919]. Kraieznavstvo ta pamiatkoznavstvo: materialy XXXIV Mizhnarodnoi kraieznavchoi konferentsii molodykh vchenykh, prysviachenoi 50-richchiu Ukrainskoho tovarystva okhorony pamiatok istorii i kultury, Kharkiv, 9 hrudnia 2016 r. Kharkiv: KhNU imeni V. N. Karazina; 2017: 8-10. (in Ukrainian).

4. Al'kov V.A. "Black Flag" of 1892: cholera epidemic and the problem of Kharkiv province peasants attitude to medical care. Inter collegas. 2015;2(3):264-274.

5. Ustinov I. A. Putevoditel' po g. Har'kovu: opisanie g. Har'kova s pril. podrob. pl. goroda s set'yu vodoprovodov i pl. teatrov: oper. i dram [Guide for the City of Kharkiv: Description of Kharkiv with the Attachment of Detailed Plans of the City with a Network of Water Pipes and Plans of Theaters: Opera and Drama]. Kharkiv: tip. V. Popova; 1881. (in Russian).

6. Har'kovskij sbornik: lit.- nauch. pril. k «Har'k. kalendaryu» na 1887 g. [Kharkiv Collection: Literary-Scientific Appendix to the «Kharkiv Calendar» for 1887]. Kharkiv:Tip. gubern. Pravleniya; 1887. (in Russian).

7. DAHO [State Achieve of the Kharkiv Region]. F. 3, 0p. 84, Spr. 140. (in Russian).

8. DAHO [State Achieve of the Kharkiv Region]. F. 3, 0p. 88, Spr. 183. (in Russian).

9. DAH0 [State Achieve of the Kharkiv Region]. F. 3, 0p. 89, Spr. 156. (in Russian).

10. Holernye epidemii v Har'kove 1830-1872. Prostituciya v Har'kove. Statisticheskij listok. [Cholera Epidemics in Kharkiv. 1830-1872. Prostitution in Kharkiv]. Statisticheskij listok. 1885;2:30-34. (in Russian).

11. Pitra A. Specimen topographiae medicae Charcowiensis: dissertatio inauguralis quam pro gradu doctoris medicinae in Caesarea Charcowiensi litterarum Universitate. Charcowiae : Tipis Universitatis; 1854.

12. Golyahovskij Ya. Pamyatnaya knizhka Har'kovskoj gubernii na 1863 god [Commemorative Book of the Kharkiv Province for 1863]. Kharkiv : Univ. Tip.; 1863. (in Russian).

13. DAHO [State Achieve of the Kharkiv Region]. F. 3, 0p. 150, Spr. 234. (in Russian).

14. DAHO [State Achieve of the Kharkiv Region]. F. 12, 0p. 1, Spr. 306. (in Russian).

15. Shchelkov K. P. Istoricheskaya hronologiya Har'kovskoj gubernii [Historical Chronology of the Kharkiv Province]. Kharkiv : Univ. tip.; 1882. (in Russian). 
16. DAHO [State Achieve of the Kharkiv Region]. F. 3, 0p. 154, Spr. 270. (in Russian).

17. DAHO [State Achieve of the Kharkiv Region]. F. 3, 0p. 154, Spr. 195. (in Russian).

18. DAHO [State Achieve of the Kharkiv Region]. F. 12, 0p. 1, Spr. 901. (in Russian).

19. DAHO [State Achieve of the Kharkiv Region]. F. 12, 0p. 1, Spr. 898. (in Russian).

20. DAHO [State Achieve of the Kharkiv Region]. F. 12, 0p. 1, Spr. 789. (in Russian).

21. DAHO [State Achieve of the Kharkiv Region]. F. 12, 0p. 1, Spr. 1027. (in Russian).

22. DAHO [State Achieve of the Kharkiv Region]. F. 314, 0p. 1, Spr. 9. (in Russian).

23. Leontovich A. Mediko-topograficheskoe i mediko-statisticheskoe opisanie Har'kovskoj gubernii [Medical-Topographic and MedicalStatistical Description of the Kharkiv Province]. Mediko-topograficheskij sbornik. Vol. 2. St. Petersburg; 1871:1-450. (in Russian).

24. Igumnov S. N. Har'kovskoe medicinskoe obshchestvo (1861-1911): ocherki ego pyatidesyatilet. deyatel'nosti [Kharkiv Medical Society (1861-1911): Sketches on Its Fifty Years Activity]. Kharkiv : Tip. i litogr. M. Zil'berberga i S-v'ya; 1913. (in Russian).

25. DAHO [State Achieve of the Kharkiv Region]. F. 3, 0p. 220, Spr. 405. (in Russian).

26. DAHO [State Achieve of the Kharkiv Region]. F. 3, 0p. 244, Spr. 93. (in Russian).

27. DAHO [State Achieve of the Kharkiv Region]. F. 52, 0p. 1, Spr. 102. (in Russian).

28. Har'kovskij kalendar' na 1878 god: (god shestoj) [Kharkiv Calendar for 1878 (the Sixth Year)]. Kharkiv : Tip. gubern. pravleniya; 1877. (in Russian).

29. Favre V. V. Sluchai holery v Har'kove osen'ju 1907 g. [Cases of Cholera in Kharkiv in the Autumn of 1907]. Kharkiv Medical Journal. 1907; 4(9): 431-434. (in Russian).

30. Utro [Morning: local newspaper]. 1907; 243. (in Russian).

31. DAHO [State Achieve of the Kharkiv Region]. F. 304, 0p. 1, Spr. 2156. (in Russian).

32. Utro. [Morning: local newspaper]. 1907; 224. (in Russian).

33. Utro. [Morning: local newspaper]. 1907; 206. (in Russian).

34. Utro. [Morning: local newspaper]. 1907; 210. (in Russian).

35. Utro. [Morning: local newspaper]. 1907; 295. (in Russian).

36. Utro. [Morning: local newspaper]. 1907; 231. (in Russian).

37. Utro. [Morning: local newspaper]. 1907; 264. (in Russian).

38. DAHO [State Achieve of the Kharkiv Region]. F. 3, 0p. 285. Spr. 325. (in Russian).

39. Har'kovskij kalendar' na 1911 god: (god tridcat' devyatyj) [Kharkiv Calendar for 1911: (Thirty-Ninth Year)]. Kharkiv:Tip. gubern. pravleniya; 1910. (in Russian).
40. Favre V. Obzor Har'kovskoj gorodskoj lechebno-sanitarnoj organizacii (1910-1914 gg.) [Overview of the Kharkiv City Medical and Sanitary Organization (1910-1914)]. Kharkiv: Prosveshchenie; [no year]. (in Russian).

41. Sovremennoe hozyajstvo goroda Har'kova (1910-1913). Vyp. 1 [Modern Economy of the City of Kharkiv (1910-1913). Issue one]. Kharkiv : Prosveshchenie; 1914. (in Russian).

42. Har'kovskij kalendar' na 1912 god: (god sorokovyj) [Kharkiv Calendar for 1911: (Fortieth Year)]. Kharkiv: Tip. gubern. pravleniya; 1911. (in Russian).

43. Hronika i melkie sobytiya [Chronicle and Minor Events]. Har'kovskij medicinskij zhurnal. 1911; 11(2): 185-186. (in Russian).

44. Hronika i melkie sobytiya [Chronicle and Minor Events]. Har'kovskij medicinskij zhurnal. 1912; 13(2): 160-161. (in Russian).

45. Hronika i melkie sobytiya [Chronicle and Minor Events]. Har'kovskij medicinskij zhurnal. 1915; 20(7): 85-86. (in Russian).

The article was prepared in frames of the theme with state registration No. 0120 U102026 "Medical Local Studies of the Kharkiv Region in the Context of Everyday Life History".

\section{ORCID and contributionship:}

Ihor Yu. Robak: 0000-0002-4837-4058 A, B, C

Volodymyr A. Alkov: 0000-0002-5339-7828 ${ }^{D}$

Hanna L. Demochko: 0000-0001-5744-5893 ${ }^{\mathrm{E}}$

Oleksandr V. Chernukha: 0000-0003-2151-2067 ${ }^{\mathrm{F}}$

\section{Conflict of interest:}

The Authors declare no conflict of interest

\section{CORRESPONDING AUTHOR \\ Volodymyr A. Alkov}

Kharkiv National Medical University

4 Nauky Ave, 61000 Kharkiv, Ukraine

tel: +380935690444

e-mail: vlalkov@rambler.ru

Received: 11.01 .2021

Accepted: 02.04 .2021

A - Work concept and design, B - Data collection and analysis, C - Responsibility for statistical analysis,

D-Writing the article, $\mathbf{E}$-Critical review, $\mathbf{F}$ - Final approval of the article 